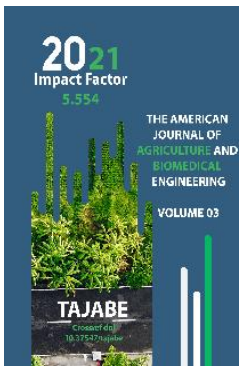

\title{
Chemical Treatment Of Water In Ammophos Production Plants
}

Mamatkulov N.N.

Almalyk Branch Of Tashkent State Technical University Named After I. Karimov, Tashkent, Republic Of Uzbekistan

Journal Website:

http://theamericanjour

nals.com/index.php/taj

abe

Copyright: Original

content from this work

may be used under the

terms of the creative

commons attributes

4.0 licence.

\section{ABSTRACT}

This paper presents purification methods for the analysis of effluents from an ammophos production plant. Chemical analysis of the waters shows that phosphorus slags and phosphogypsum contain harmful elements such as strontium, arsenic, cadmium, titanium and manganese. Theoretical work on the control of ammophos max wastewater. Wastewater was found to contain Ca, Mg, F, S, P, N2 and trace elements.

\section{KEYWORDS}

Ammophos, phosphogypsum, fertilizer, moisture, fluorine, phosphorus, sublimation, strontium, arsenic, cadmium, phosphorus type, industry, waste, suspension, emulsion, diluent.

\section{INTRODUCTION}

As a result of the production activities of the ammophos production plant, more than 10 million tons of phosphorus fertilizers, especially phosphogypsum, were accumulated in the landfills of phosphorous plants.

Currently, a number of methods are used in the treatment of sewage and wastewater. The most important of these are mechanical, chemical, electrolytic, biological treatment methods.

The ammophos production plant uses a mechanical cleaning method. In the mechanical treatment of polluted wastewater, a special structure is built, which retains water-insoluble substances. If the volume of impurities in the water is greater than $5 \mathrm{~mm}$, it is caught by means of an iron grid, if it is 
smaller, by means of iron nets. Liquids floating on dirty water are caught with grease, grease, grease traps, grease traps. Wastewater is also treated in special clarifiers, solid particles are precipitated, and light ones are brought to the surface of the water and trapped $[1,2,3]$.

In the chemical treatment method, reagents (reagents) are added to the wastewater, reacted, and the dissolved and insoluble contaminants are precipitated or neutralized. Chemical treatment of wastewater can remove up to $95 \%$ of insoluble substances in water and up to $25 \%$ of dissolved solids.

Under the influence of temperature differences, atmospheric influences, humidity and wind, they are gradually destroyed. They emit dust and release toxic gases in the form of $\mathrm{HF}$ (hydrogen fluoride) and $\mathrm{PH}_{3}$ (phosphine). The tendency of fluorides and phosphines in the waste to dissolve in water leads to leaching of groundwater and surface water. Thus, according to the data in the groundwater of the city of Taroz, the amount of fluorine is $8.2-8.4 \mathrm{mg}$, which is 8 times higher than the MPC. In humans and pets, 1-2 $\mathrm{mg}$ in water, toothpaste and bone fluorosis develops [4-6]. Dust containing fluorine and phosphorus compounds also causes eye and respiratory diseases, contributes to the development of cardiovascular failure, kidney, liver and stomach infections will give.

\section{THE MAIN PART}

Extensive use of man-made raw materials in the production of road materials is currently impossible without careful chemical-analytical research. Therefore, chemical analyzes were performed as atomic adsorption using a modern adsorption method, which added to the rock-forming elements. to detect rare heavy metals, radioactive elements and others allows. Phosphorus group is a complex multicomponent substance, the basis of which $\mathrm{CaO}-\mathrm{SiO}_{2}-\mathrm{P}_{2} \mathrm{O}_{5}$ system and the amount of $\mathrm{AbO}_{3}, \mathrm{MgO}, \mathrm{Fe}_{2} \mathrm{O}_{3}, \mathrm{Na}_{2} \mathrm{O}$ in the nutrient content and the process of sublimation of phosphorus. depending on. The chemical composition of phosphorus slags is similar to blast furnaces, but they are characterized by low content of $\mathrm{Al}_{2} \mathrm{O}_{3}, \mathrm{MgO}, \mathrm{Fe}_{2} \mathrm{O}_{3}, \mathrm{Na}_{2} \mathrm{O}$, and in addition contain phosphorus and fluorine oxides. In terms of radioactivity, these chemical industrial wastes meet the requirements of "Radiation Safety Standards (NRB-99)" and are free of radiation factors in any construction. can be used.

Chemical analysis data show that phosphorus slag and phosphogypsum contain harmful elements such as strontium, arsenic, cadmium, titanium and manganese.

It is impossible or very difficult to remove the toxins in the toxic substances and the reserves of pure natural raw materials are very limited. In this regard, the production of environmentally friendly building materials from industrial waste is a promising direction to expand the raw material base of the construction materials industry, develop production, reduce the cost of construction products, prevent new waste and reduce the need for equipment for new landfills.

A comprehensive assessment of the environmental pollution of the phosphoric group and phosphogypsum is necessary to make recommendations for their use. The rate of environmental pollution was determined by the formula 


$$
{ }_{i=1}^{m} P_{e z}=\Sigma\left(K_{p i}\right)+K x \Sigma\left(m_{g} x K_{x g}\right)
$$

Here, copper and magnesium are the mass fractions of one ton of raw material, unit fractions, of radioactive and chemical contaminants, respectively;

$K_{p i^{-}}$the relative risk coefficient of natural radionuclides is determined as follows: $K_{p i}=$ $A_{f f}$ /370;
$\mathrm{K}$ - is the coefficient taking into account the combined action of different chemical contaminants

$K_{x g}$ - The relative environmental and economic hazard coefficient of the pollutant is determined in accordance with. The environmental pollution indicators of industrial wastes calculated according to the formula are given in Table 1.

Table 1 - Indicators of environmental pollution of phosphorus slag and phosphogypsum

\begin{tabular}{|c|c|c|c|c|}
\hline № $t / r$ & Name of Waste & Pez min & Pez max & Pez sr \\
\hline 1 & Phosphorus form & 1,02 & 1,4 & 1,21 \\
\hline 2 & phosphogypsum & 1,3 & 1,78 & 1,54 \\
\hline
\end{tabular}

\section{Technological part}

Natural waters are divided into the following classes according to the amount of dissolved salts, ie minerals: (in $\mathrm{g} / \mathrm{l}$ )

1) Fresh water (less than <1 g/ I);

2) Slightly salty (1-10);

3) Salt (10-50);

4) Moisture content (> $50 \mathrm{~g} / 1)$.

Theoretical work on the control of ammophos max wastewater. Wastewater was found to contain $\mathrm{Ca}, \mathrm{Mg}, \mathrm{F}, \mathrm{S}, \mathrm{P}, \mathrm{N}_{2}$ and trace elements. These waters were considered useful for agricultural crops. It is clear that water has a positive effect on rural waters. Industrial waste comes in many forms. They can also occur in a mixture of suspension and emulsion. They need to be re-cleaned when they come out of the process equipment without waste. Examples of these devices. Information on the use of vertical clarifiers in industry has been obtained. 


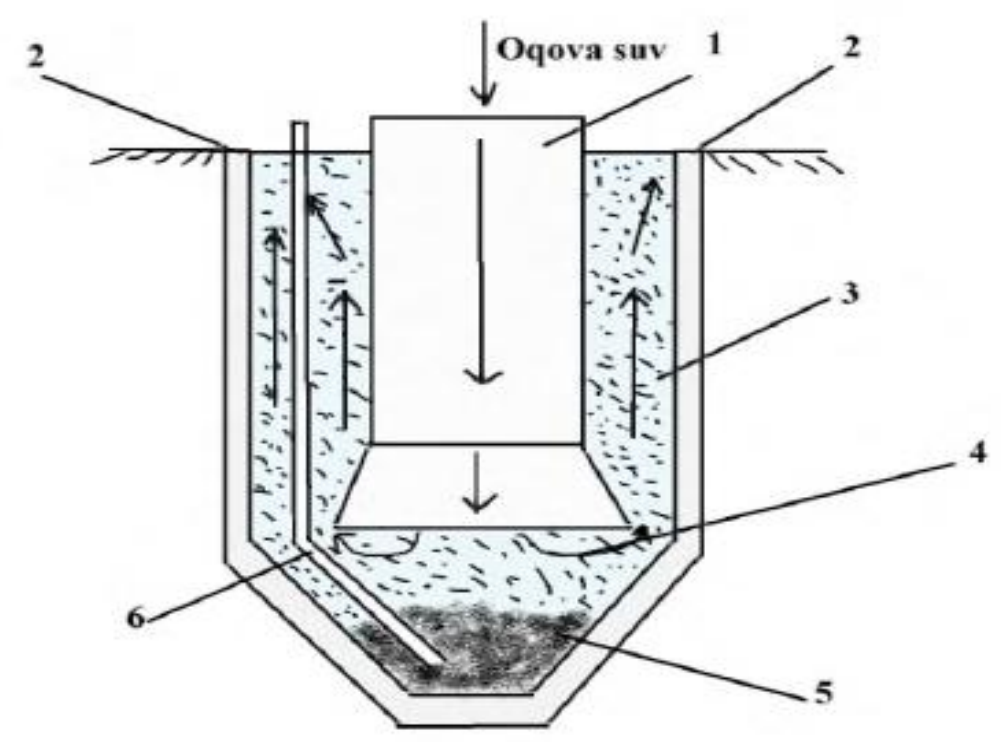

Figure 1. Vertical breaker: 1- central pipe; 2-circulating drainage ditch; 3-part of the search; 4Reflector ;5-Well ;6 -mud weighing device.

The drain is a cylindrical reservoir with a conical base, through which the sewage is supplied through a central pipe. The water then moves from the bottom to the top and is discharged through a ditch.

\section{CONCLUSION}

As a result, the particles in the water move down under their own gravity. And the height of the sinking zone is 4-5 m. At the end of the qualifying study, it was analyzed that the efficiency of the vertical breaker is $10-20 \%$ less than that of the horizontal breaker.

\section{REFERENCES}

1. Mamatkulov, N. N. (2019). Nahozhdenie uslovij sintezirovanija i opredelenie biologicheskoj aktivnosti fenilbenzoiloksiacetata [Finding the conditions for synthesizing and determining the biological activity of phenylbenzoyloxyacetate]. Voprosy nauki i obrazovanija, (15 (62)). (in Russian.)

2. Mamatkulov, N. N. (2020). Opredelenie optimal'nyh uslovij sinteza ptolilbenzoiloksiacetata [Determination of optimal conditions for synthesis of $\mathrm{p}$ tolylbenzoyloxyacetate]. Vestnik nauki i obrazovanija, (10-2 (88)). (in Russian.)

3. Madusmanova, N. K. (2020). Sorbcionnospektrofotometricheskoe opredelenie ionov zheleza iz obektov okruzhajushhej sredy [Sorption-spectrophotometric determination of iron ions from environmental objects]. Vestnik nauki i obrazovanija, (10-2 (88)), 16-18. (in Russian.)

4. Madusmanova, N. K. (2020). Fotometricheskoe opredelenie vismuta $\mathrm{S}$ pomoshh'ju reagenta 1-(5-metil-2piridilazo)-5-dijetilaminofenola. Vestnik nauki i obrazovanija, (11-2 (89)) 
[Photometric determination of bismuth using the reagent 1- (5-methyl-2pyridylazo) -5-diethylaminophenol]. (in Russian.)

5. Mamatkulov, N. N., Abdushukurov, A. K., Khidirov, S., \& Rakhmonova, S. (2001). Synthesis and rearrangement of p-tolyl chloroacetate. Russian journal of organic chemistry, 37(11), 1668-1669.

6. Pulatov, G. M. (2020). Izuchenie tehnologii primenenija mikroorganizmov pri ochistke stochnyh vod [Study of the technology of using microorganisms in wastewater treatment]. Vestnik nauki i obrazovanija, (10-2 (88)). (in Russian.) 